University of Nebraska - Lincoln

DigitalCommons@University of Nebraska - Lincoln

Publications, Agencies and Staff of the U.S.

Department of Commerce

U.S. Department of Commerce

2009

Diet of Pygmy Sperm Whales (Kogia breviceps) in the Hawaiian Archipelago

\author{
Kristi West \\ Hawai'i Pacific University, 45-045 Kamehameha Highway, Kaneohe, Hawai'i \\ William Walker \\ National Marine Fisheries Service, NOAA \\ Robin Baird \\ Olympia, Washington \\ Whitney White \\ Hawai'i Pacific University, 45-045 Kamehameha Highway, Kaneohe, Hawai'i \\ Gregg Levine \\ Kailua, Hawai'i \\ See next page for additional authors
}

Follow this and additional works at: https://digitalcommons.unl.edu/usdeptcommercepub

Part of the Environmental Sciences Commons

West, Kristi; Walker, William; Baird, Robin; White, Whitney; Levine, Gregg; Brown, Eric; and Schofield, David, "Diet of Pygmy Sperm Whales (Kogia breviceps) in the Hawaiian Archipelago" (2009). Publications, Agencies and Staff of the U.S. Department of Commerce. 18.

https://digitalcommons.unl.edu/usdeptcommercepub/18

This Article is brought to you for free and open access by the U.S. Department of Commerce at DigitalCommons@University of Nebraska - Lincoln. It has been accepted for inclusion in Publications, Agencies and Staff of the U.S. Department of Commerce by an authorized administrator of DigitalCommons@University of Nebraska - Lincoln. 


\section{Authors}

Kristi West, William Walker, Robin Baird, Whitney White, Gregg Levine, Eric Brown, and David Schofield 
This article is a U.S. government work, and is not subject to copyright in the United States.

MARINE MAMMAL SCIENCE, **(*): ***_***(*** 2009)

(C) 2009 by the Society for Marine Mammalogy

DOI: $10.1111 /$ j.1748-7692.2009.00295.x

\title{
Diet of pygmy sperm whales (Kogia breviceps) in the Hawaiian Archipelago
}

\author{
KRISTI L. WeST \\ College of Natural Sciences, \\ Hawai'i Pacific University, \\ 45-045 Kamehameha Highway, \\ Kaneohe, Hawai'i 96744, U.S.A. \\ E-mail: kwest@hpu.edu \\ William A. Walker \\ National Marine Mammal Laboratory, \\ Alaska Fisheries Science Center, \\ National Marine Fisheries Service, NOAA, \\ 7600 Sand Point Way N.E., \\ Seattle, Washington 98115, U.S.A. \\ ROBIN W. BAIRD \\ Cascadia Research Collective, \\ $2181 / 2 \mathrm{~W}$. 4th Avenue, \\ Olympia, Washington 98501, U.S.A. \\ Whitney White \\ College of Natural Sciences, \\ Hawai'i Pacific University, \\ 45-045 Kamehameha Highway, \\ Kaneohe, Hawai'i 96744, U.S.A. \\ GREGG LeVINE \\ 267 S. Kalaheo Avenue, \\ Kailua, Hawai'i 96744, U.S.A. \\ ERIC BROWN \\ National Park Service, \\ Kalaupapa National Historical Park, \\ P. O. 2222, Kalaupapa, Hawai'i 96742, U.S.A.

\section{DAVID SCHOFIELD} \\ NOAA Pacific Islands Regional Office, \\ National Marine Fisheries Service, \\ 1601 Kapiolani Boulevard Suite 1110, \\ Honolulu, Hawai'i 96814, U.S.A.
}

The biology and ecology of the pygmy sperm whale (Kogia breviceps) is poorly understood among odontocetes (McAlpine 2002). In Hawaiian waters, pygmy sperm whales are the second most frequently recorded stranded cetacean species, with 35 strandings documented between 1963 and 2008 (Shallenberger 1981, Nitta 1987, 
Table 1. Pygmy sperm whales stranded in the Hawaiian Islands between 1986 and 2008 where stomach contents were examined.

\begin{tabular}{|c|c|c|c|c|c|}
\hline $\begin{array}{l}\text { Status at } \\
\text { stranding }\end{array}$ & $\begin{array}{c}\text { Date of } \\
\text { stranding }\end{array}$ & Sex & $\begin{array}{l}\text { Reproductive } \\
\text { status }\end{array}$ & $\begin{array}{c}\text { Body } \\
\text { length }(\mathrm{cm})\end{array}$ & $\begin{array}{l}\text { Location of } \\
\text { stranding }\end{array}$ \\
\hline Dead & 8 January $1986^{a}$ & M & Mature & 301 & Kalaupapa, Moloka'i \\
\hline Alive and died & & & & & \\
\hline on site & 3 June 2000 & M & Immature & 244 & Na Pali coast, Kaua 'i \\
\hline Alive and later & & & & & \\
\hline euthanized & 15 January 2005 & $\mathrm{~F}$ & Mature (with calf) & 295 & Kihei, Maui \\
\hline Dead & 20 May 2006 & M & Mature & 306 & Kalaupapa, Moloka'i \\
\hline Dead & 15 April $2007^{a}$ & $\mathrm{~F}$ & Mature (pregnant) & 315 & Lana'i \\
\hline Dead & 25 April 2007 & M & Mature & 307 & Kihei, Maui \\
\hline Dead & 1 January 2008 & $\mathrm{~F}$ & Immature & 215 & Midway atoll \\
\hline
\end{tabular}

${ }^{a}$ The 2007 Lana' $i$ and the 1986 Kalaupapa stranding date represent the dates of the initial observation. The individual from Lana $i$ was found in a remote area of the island in a moderate state of decomposition and likely stranded at an earlier date.

Maldini et al. 2005, NMFS database ${ }^{1}$ ). Despite the high frequency of strandings, sightings of this species in Hawaiian waters are rare (Baird 2005). Given the low number of sightings, examination of stranded animals provides virtually the only means to study the biology and ecology of pygmy sperm whales in the area.

Pygmy sperm whales are recorded as feeding primarily on cephalopods from most locations where stomach contents have been examined (Wang et al. 2002, Bustamante et al. 2003, Santos et al. 2006, Beatson 2007). However, diet composition has not been previously examined for pygmy sperm whales from any location in the central Pacific Ocean. The primary objective of our study was to assess the diet of pygmy sperm whales in Hawai' $i$ through the examination of stomach contents of seven stranded specimens. In addition, we compare the diet composition of pygmy sperm whales in the Hawaiian Islands with that of whales from other geographic locations.

Stomach contents were collected from six of 16 pygmy sperm whales that stranded between 2000 and 2008 in the Hawaiian Islands and from one individual that stranded in 1986. Additional information on date of stranding, body length, and specific location is provided in Table 1 . In all but one case, pygmy sperm whales were identified to species based on both the location of the dorsal fin and a height measurement that was less than $5 \%$ of the total body length (five of the seven were also longer than the known maximum body length for dwarf sperm whales). For the Midway individual, genetic analyses performed by the Southwest Fisheries Science Center was necessary to confirm the species identification.

Stomach contents were initially frozen for six of the pygmy sperm whales and fixed in formalin for one of the whales. Frozen contents were later thawed and each sample was then rinsed through a progression of sieves with decreasing mesh sizes of $1.4 \mathrm{~mm}$, $0.94 \mathrm{~mm}$, and $0.50 \mathrm{~mm}$. After sorting, cephalopod beaks, fish bones and crustacean

\footnotetext{
${ }^{1}$ Available from Pacific Islands Regional Office, NOAA National Marine Fisheries Service, 1601 Kapiolani Boulevard, Suite 1110, Honolulu, HI 96814.
} 
remains were preserved in $70 \%$ ethanol. Fish otoliths were stored dry in gelatin capsules. All remains were identified to the lowest possible taxon using the private reference collection of W. A. Walker and the fish bone, otolith and cephalopod beak reference collections housed at the National Marine Mammal Laboratory (NMML), Seattle, Washington. A voucher series of select beaks and otoliths representing each prey taxon were removed from the individual stomach samples and incorporated into the NMML reference collections. The remainder of the individual stomach samples were stored in alcohol at NMML.

A total number of each species of cephalopod was estimated as the number of lower beaks present. A total number of each fish species was estimated based on the greater number of left and right otoliths. In a few instances, the number of fish prey was estimated based on the greater number of left or right paired cranial bones. Crustacean abundance was estimated using the number of individual carapace remains in each stomach.

Dorsal mantle length and total weights were estimated by measuring lower beak rostral length for the cephalopod decapods and lower beak hood length for the cephalopod octopods and then applying the appropriate regression equations. Cephalopod beaks were measured to the nearest $0.1 \mathrm{~mm}$ with either an optical micrometer or, in the case of large beaks, Vernier calipers. With three exceptions, all regression equations came from Clarke (1986). There were no regression equations available for Enoploteuthis sp. cf. E. reticulata, Japatella sp., and Ocythoe tuberculata. Prey size for these species were estimated using data from individuals of near equivalent beak size housed in the NMML reference collection. Following Clarke (1986), pigmentation (darkening) of the wing portions of the lower beak were recorded for beaks of Stigmatoteuthis hoylei, Taonius pavo, Liocranchia reinhardti, and Mastigoteuthis famelica. Beaks were considered to be from adult squid when the wing pigmentation was complete. Fish otoliths and diagnostic bones were measured to the nearest $0.1 \mathrm{~mm}$ using an optical micrometer. In most cases, fish prey standard lengths and weights were estimated using regression equations from the literature (Smale et al. 1995, Ohizumi et al. 2001, Spear et al. 2007), or from regressions developed for similar, closely related species at NMML. In instances where appropriate weight regressions were unavailable, weight was estimated by comparison with other closely related species of similar size. Of the two crustaceans documented, carapace length and weight relationships had only been described for Gnathophausia ingens. As a result, weights were estimated for both species of shrimp by measuring carapace length and then applying the regression equation available for $G$. ingens (Childress and Price 1983).

Together the seven stomachs of pygmy sperm whales examined contained a total of 728 food items ranging from 12 to 300 prey items/stomach and six to 28 species/stomach. Predominant prey remains were cephalopod beaks. A total of 573 lower beaks were identified representing 17 families and 38 species (Table 2). Fish and crustaceans also contributed to the stomach contents. Five of the seven stomachs also contained fish remains representing 11 families, which comprised a total of $6.9 \%$ by number and $3.3 \%$ by mass. Two species of deep-water shrimp contributed $14.4 \%$ by number and $3.4 \%$ by mass to Hawaiian pygmy sperm whale diet. 


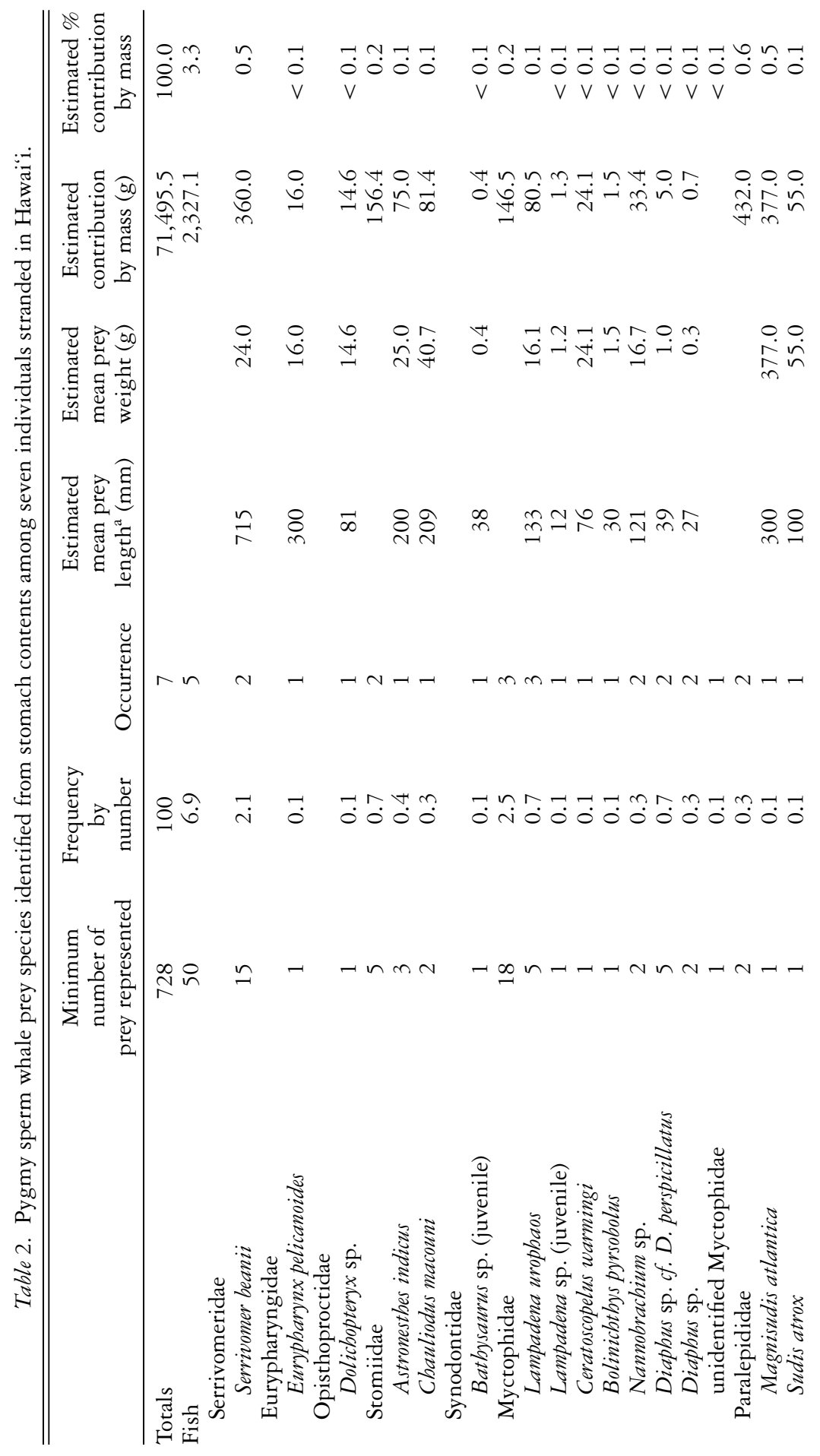




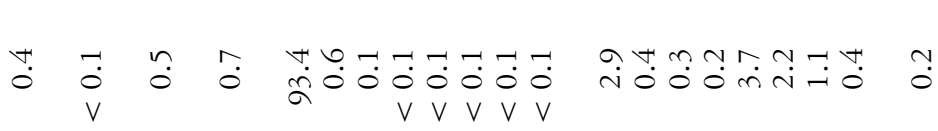

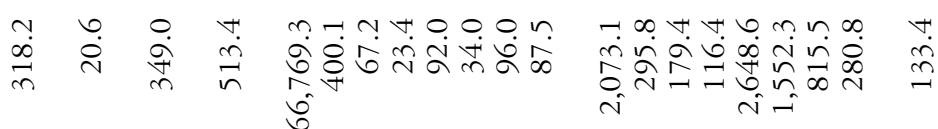

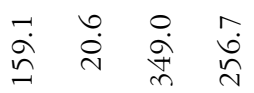

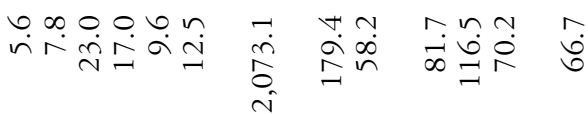

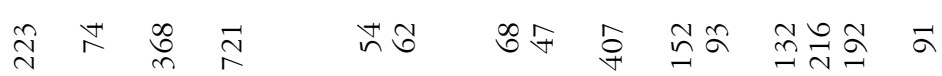

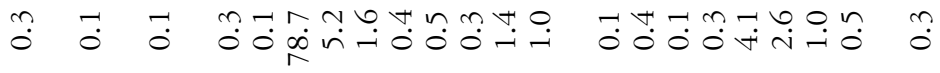

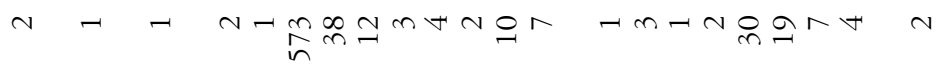

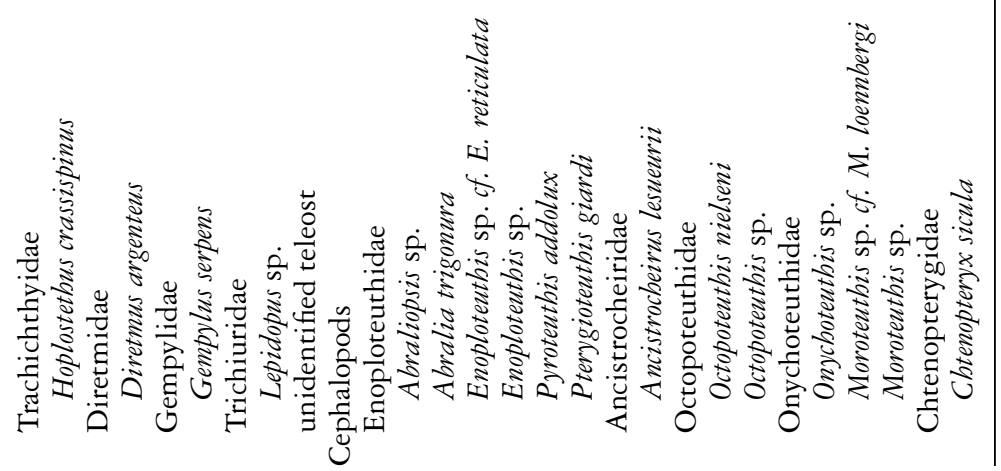




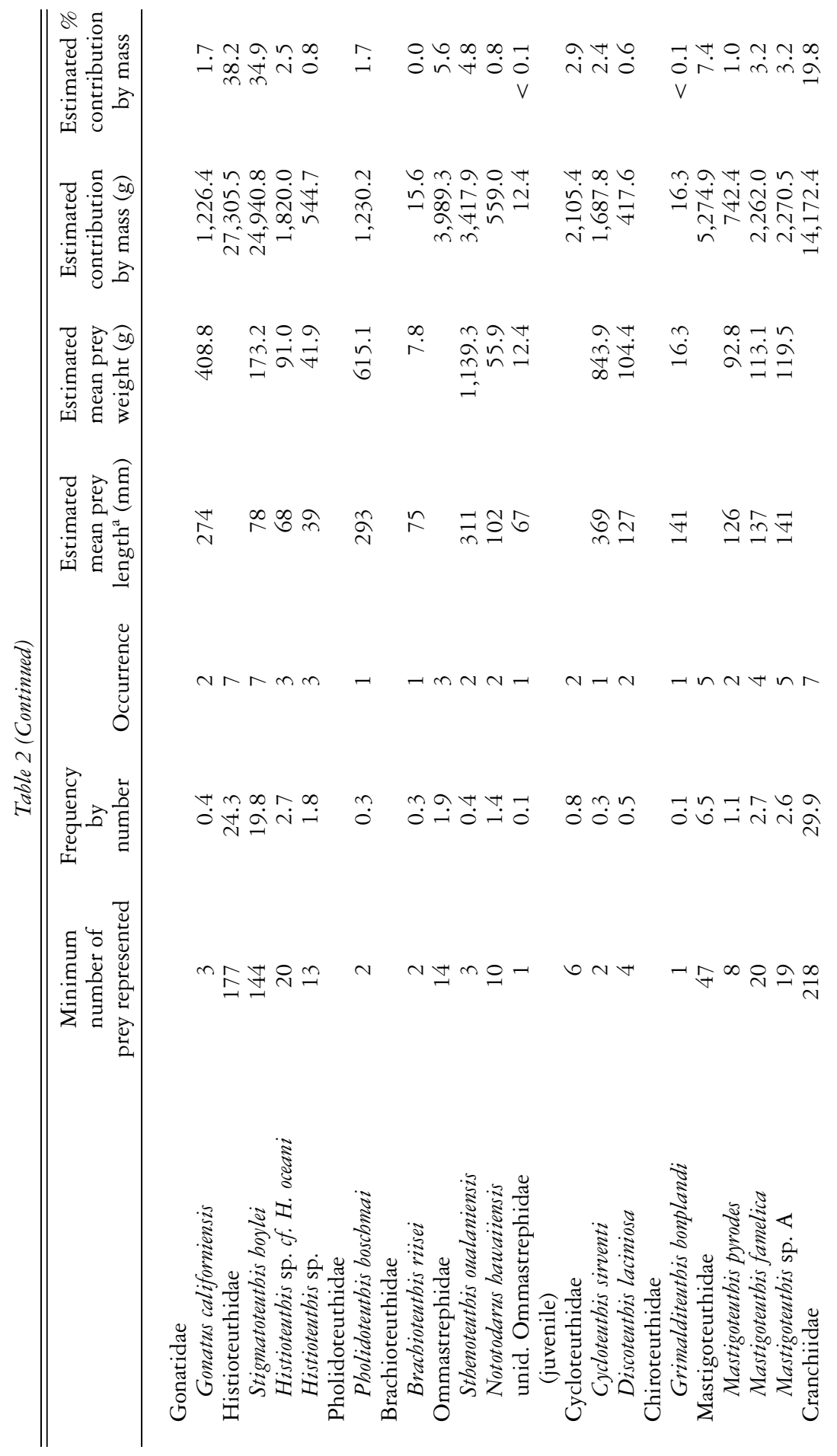




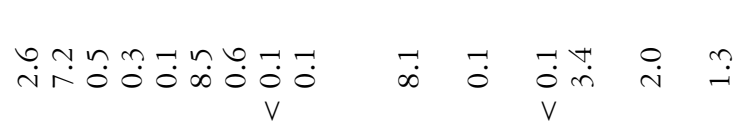

$\infty \circ \infty \forall \because n 0 \infty 0$

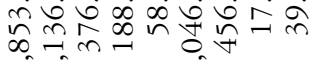

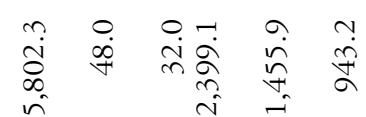

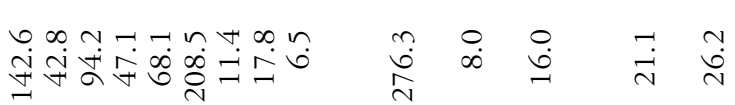

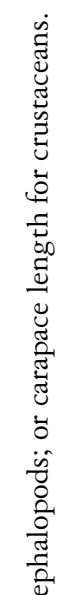

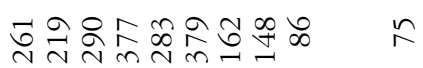

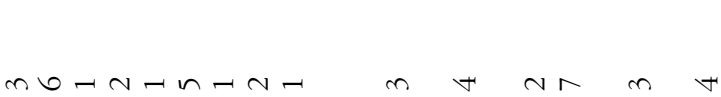

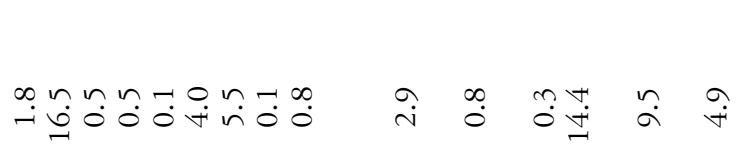

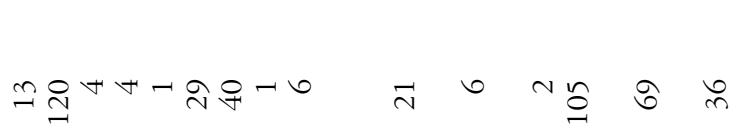

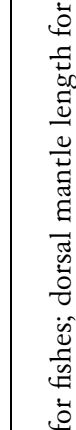


The two most numerically abundant cephalopod families were Histioteuthidae $(24.3 \%)$ and Cranchiidae (29.9\%). These two families were found in all seven stomachs and collectively represented an estimated $58.0 \%$ of the total prey mass. The histioteuthid Stigmatoteuthis boylei was found in all of the seven stomachs and represented $19.8 \%$ of the total abundance with estimated dorsal mantle lengths ranging from $38 \mathrm{~mm}$ to $149 \mathrm{~mm}$ (Fig. 1A). The total estimated weight contribution of S. hoylei was $34.9 \%$. Representatives of the family Cranchiidae were dominated by Taonius pavo, found in six of the seven stomachs and constituting $16.5 \%$ of the total prey items. Estimated size for this prey species ranged from $98 \mathrm{~mm}$ to $326 \mathrm{~mm}$ and contributed $7.2 \%$ to the estimated total prey weight (Fig. 1B). Another cranchiid, Liocranchia reinhardti was found in five of the seven stomachs, represented $4.0 \%$ of the prey items, contributed $8.5 \%$ by weight and ranged in size from $281 \mathrm{~mm}$ to $462 \mathrm{~mm}$ (Fig. 1C). Remains of the vampyroteuthid, the vampire squid (Vampyroteuthis infernalis) were found in three of the seven stomachs examined and comprised $2.9 \%$ of the prey items with an estimated contribution by mass of $8.1 \%$. Estimated mantle lengths for this species ranged from $43 \mathrm{~mm}$ to $118 \mathrm{~mm}$ (Fig. 1D).

Bean's sawtoothed eel (Serrivomer beanii) was the most common fish species ingested, representing $2.1 \%$ of the prey items identified and contributing $0.5 \%$ to the total prey weight. Members of the lanternfish family Myctophidae were not represented in high numbers, however, seven species of these fishes were identified (Table 2). The crustacean Pasiphaea tarda was found in three of the seven stomachs and contributed $9.5 \%$ to the total prey abundance and $2.0 \%$ by weight. Carapace length of this deepwater shrimp ranged between $40 \mathrm{~mm}$ and $65 \mathrm{~mm}$ (Fig. 2A). Another crustacean, Gnathophausia ingens, was found in four of the seven stomachs, contributed $4.9 \%$ to total prey abundance and $1.3 \%$ by weight. Carapace length ranged between $41 \mathrm{~mm}$ and $79 \mathrm{~mm}$ (Fig. 2B).

The primary prey of pygmy sperm whales in Hawaiian waters consists of a wide diversity of cephalopods. While it is often difficult to infer the foraging depth of predators from cephalopod prey remains (Roper and Young 1975), our results provide insight into the foraging depth and feeding preferences of pygmy sperm whales in Hawai' $i$ as three of the 10 most abundant cephalopod prey species found in our stomachs (Taonius pavo, the vampire squid, and Mastigoteuthis famelica) do not undergo diel migrations.

Taonius pavo juveniles are found primarily between $600 \mathrm{~m}$ to $650 \mathrm{~m}$ and adults between $725 \mathrm{~m}$ and $970 \mathrm{~m}$ both day and night (Young 1975), the vampire squid is found between depths of $800 \mathrm{~m}$ and 1,200 m off O'ahu (Young 1978), and Mastigoteuthis famelica were taken off $\mathrm{O}^{\prime}$ ahu between $675 \mathrm{~m}$ and $800 \mathrm{~m}$ during both day and night (Young 1978). The reported depths for these three important prey species suggest that in Hawai' $i$ pygmy sperm whale dive behavior spans both the mesopelagic and bathypelagic zones and at least some foraging occurs between $600 \mathrm{~m}$ and $1,200 \mathrm{~m}$.

Mesopelagic fish species were found to contribute to pygmy sperm whale diets in Hawai' $i$, comprising $6.9 \%$ of the total prey items, but only $3.3 \%$ by mass (Table 2 ). Although generally low in abundance, a wide diversity of fish species (19) from 11 different families was found among the seven stomachs. Bean's sawtoothed eel was 
A

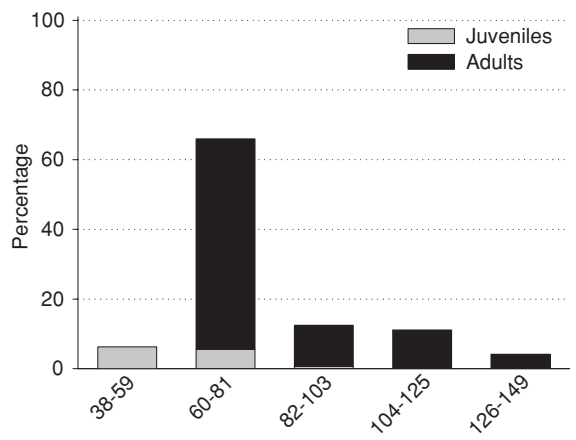

B

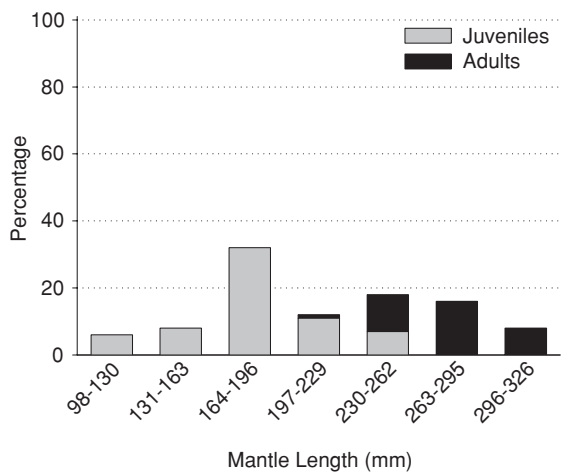

C

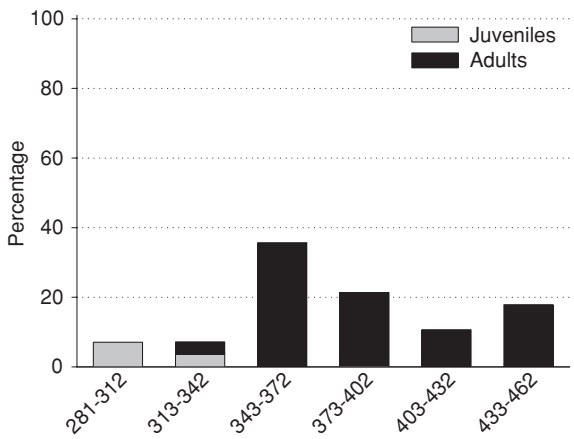

D

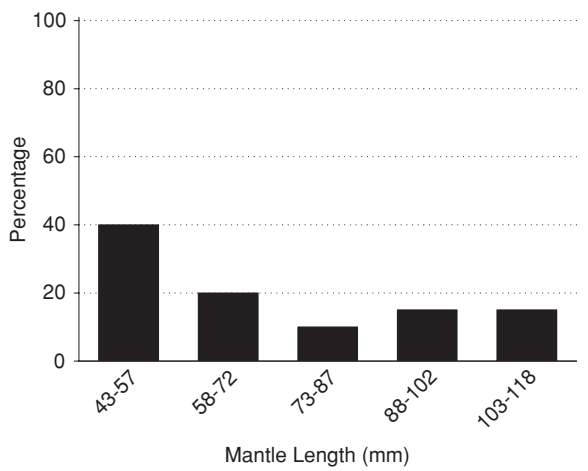

Figure 1. Frequency distribution of estimated mantle length and state of maturity of (A) Stigmatoteuthis hoylei (B) Taonius pavo (C) and Liocranchia reinhardti. Only estimated mantle length is provided for (D) Vampryotheuthis infernalis. Prey items were combined for the seven pygmy sperm whales.

the most abundant and contributed the highest proportion by mass of the deep-water fish species. Struhsaker (1973) collected specimens at depths of $640 \mathrm{~m}-869 \mathrm{~m}$ from the island of Hawai' $i$ to Kaua' $i$ and over 50 specimens of Serrivomer sp. were collected during day trawls between the depths of $735 \mathrm{~m}$ and $960 \mathrm{~m}$ off leeward O'ahu (Reid et al. 1991).

Two abundant species of mesopelagic crustaceans, Pasiphaea tarda and Gnathophausia ingens, found in this study have a wide distribution. $P$. tarda has been reported from both the Atlantic and Pacific oceans and $G$. ingens is common in tropical and subtropical regions worldwide (Hanamura and Evans 1994). G. ingens has been collected between $400 \mathrm{~m}$ and 1,200 m off O'ahu (Sanders and Childress 1990).

Cephalopods were the primary prey of pygmy sperm whales in Hawaiian waters making up $78.7 \%$ of prey abundance and $93.4 \%$ contribution by mass. Our stomach samples revealed an extreme diversity of cephalopod prey with 38 species from 17 different families. Especially given our sample size of only seven stomachs, this demonstrates a highly varied diet composition compared to almost all other regions 
A

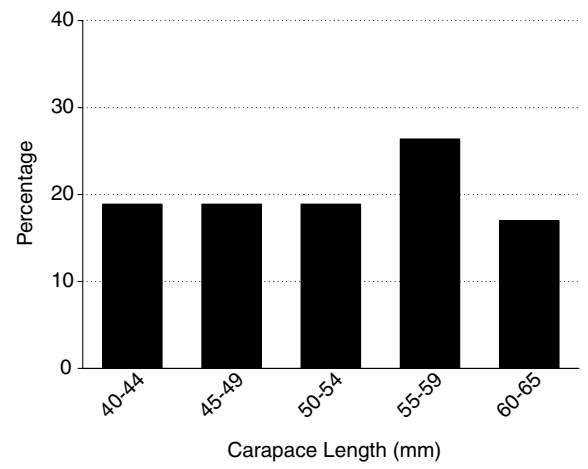

B

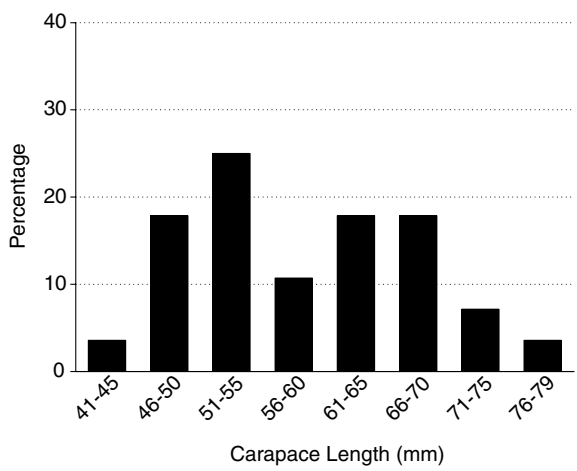

Figure 2. Frequency distribution of estimated size based on carapace length of (A) Pasiphaea tarda and (B) Gnathophausia ingens combined for the seven pygmy sperm whales.

where pygmy sperm whale stomach contents have been investigated. The only study in which more than 17 families of cephalopod prey were identified is that of Plön (2004), where 42 stomachs were examined in South Africa.

As already reported for the diet of this species cephalopods of the family Histioteuthidae are the most abundant prey ingested (Ross 1979, Klages et al. 1989, Sekiguchi et al. 1992, Plön 2004, Santos et al. 2006, Beatson 2007). Histioteuthids were also abundant in the stomachs from Hawai' $i$, where they were the second most abundant family and the greatest contributor by weight (Table 2). Taiwan is the only location where a study of pygmy sperm whale diet did not list histioteuthids as a dominant prey family. Wang et al. (2002) reported that this family contributed $8 \%$ to the diet by number and $10 \%$ by weight. The cephalopod family Cranchiidae has also been recognized as important to the diet of pygmy sperm whales from most geographic locations (Candela 1987, Wang et al. 2002, Beatson 2007). Cranchiids were the most abundant family (29.9\%) of cephalopod prey represented in the Hawaiian pygmy sperm whale stomachs. However, they ranked second in terms of their contribution by mass $(19.8 \%)$. Prey from this family have also been shown to be a major component of the diet of pygmy sperm whales in studies conducted off Taiwan (Wang et al. 2002), the southeastern United States (Candela 1987), in New Zealand (Beatson 2007), and as a dominant prey family in one of four studies conducted in South Africa (Ross 1979, Klages et al. 1989, Sekiguchi et al. 1992, Plön 2004).

The deep-water fish contribution to Hawaiian pygmy sperm whale diet was found to be similar to that of South Africa. Fish were present in $71 \%$ of the Hawaiian stomachs and in $75 \%$ of South African stomachs examined (Ross 1979). Mesopelagic fish contributed $6.9 \%$ to prey abundance in Hawai $i$, whereas two studies from South Africa demonstrated a similar contribution of $9.1 \%$ and $10.3 \%$ (Klages et al. 1989, Plön 2004).

Crustaceans were found to be a significant component of the diet of pygmy sperm whales in Hawaiian waters when compared to reports from other regions. 
Collectively, Pasiphaea tarda and Gnathophausia ingens accounted for almost $15 \%$ of the prey abundance and $3.4 \%$ by weight, a level not observed in other studies. No accounts of crustacean remains were reported in six stomachs from Taiwan (Wang et al. 2002). Beatson (2007) examined 27 stomachs from New Zealand waters where crustaceans were found to comprise $<4 \%$ of the diet based on the abundance of prey. However, on a species level, the presence of $G$. ingens was similar between the Hawai' ${ }^{i}$ ( $4.9 \%$ by prey abundance) and New Zealand stomachs (3.2\% by prey abundance).

Most of what is known about pygmy sperm whales comes from waters off South Africa where a greater number of stomachs have been examined than for any other geographic location. Ross (1979) reported the presence of crustaceans in $75 \%$ of stomachs examined, represented by Gnathophausia sp. in more than half of the stomachs. In a more recent study in South Africa, crustaceans were found to contribute $2.5 \%$ to prey abundance and $1.1 \%$ for the species $G$. ingens (Plön 2004). In the northeastern Atlantic, crustacean prey appeared to play a minor role in the diet of the 14 whales examined (Santos et al. 2006), being found in only one individual where the stomach contents consisted entirely of 29 swimming crabs, Polybius henslowii.

Prior to this investigation of diet composition from seven stranded pygmy sperm whales in Hawai' $\mathrm{i}$, little was known of the feeding ecology of Kogia in the central Pacific. Findings from this study suggest that pygmy sperm whales eat a wide diversity of prey and engage in foraging activity between $600 \mathrm{~m}$ and $1,200 \mathrm{~m}$ in Hawaiian waters, spanning both the mesopelagic and bathypelagic zones.

\section{ACKNOWLEDGMENTS}

We would like to thank John Klavitter, Thierry Work, and other stranding responders involved in the collection of the pygmy sperm whale stomach contents. We are also grateful to Jeffery Drazen, Brad Seibel, and Steve Haddock for assistance in the interpretation of our results. Richard Young was particularly helpful in sharing his knowledge on the vertical distribution of Hawaiian cephalopods and provided assistance in the identification of the histioteuthid and mastigoteuthid beaks. Susan Chivers confirmed the species identification of the Midway individual. We also thank Mariana Kuprijanova for her assistance with the references and Nicole Davis for her efforts to track down one of the missing samples. We would also like to thank the Prescott grant program for supporting stranding response efforts in the Pacific Islands region.

\section{Literature Cited}

BAIRD, R. W. 2005. Sightings of dwarf (Kogia sima) and pygmy (K. breviceps) sperm whales from the main Hawaiian Islands. Pacific Science 59:461-466.

Beatson, E. 2007. The diet of pygmy sperm whales, Kogia breviceps, stranded in New Zealand: Implications for conservation. Reviews in Fish Biology and Fisheries 17:295-303.

Bustamante, P., C. Garrigue, L. Breau, F. Caurant, W. Dabin, J. Greaves and R. DODEMONT. 2003. Trace elements in two odontocete species (Kogia breviceps and Globicephala macrorbynchus) stranded in New Caledonia (South Pacific). Environmental Pollution 124:263-271.

CANDELA, S. N. 1987. Cephalopod prey of pygmy and dwarf sperm whales (Kogia breviceps and K. simus) stranded in Florida and Georgia. Seventh Biennial Conference on the Biology of Marine Mammals, 5-7 December 1987, Miami, FL. 9 pp. 
Childress, J. J., AND M. H. Price. 1983. Growth rate of the bathypelagic crustacean Gnathophausia ingens (Mysidacea: Lophogastridae). Marine Biology 76:165-177.

Clarke, M. R. 1986. Cephalopods in the diet of odontocetes. Pages 281-321 in M. M. Bryden and R. Harrison, eds. Research on dolphins. Clarendon Press, Oxford, UK.

Hanamura, Y., And D. R. Evans. 1994. Deepwater caridean shrimps of the families Oplophoridae and Pasiphaeidae (Crustacea: Decapoda) from western Australia, with an appendix on a lophogastridan mysid (Mysidacea). Crustacean Research 23:4660 .

Klages, N., V. G. Cockcroft And P. B. Best. 1989. Stomach contents of pygmy Kogia breviceps and dwarf $K$. simus sperm whales stranded on South African beaches. Eighth Biennial Conference on the Biology of Marine Mammals, 7-11 December 1989, Pacific Grove, CA. 35 pp.

Maldini, D., L. MazZuCa and S. Atkinson. 2005. Odontocete stranding patterns in the Main Hawaiian Islands (1937-2002): How do they compare with live animal surveys? Pacific Science 59:55-67.

MCAlpine, D. 2002. Pygmy and dwarf sperm whales. Pages 1007-1009 in W. F. Perrin, B. Würsig, and J. G. M. Thewissen, eds. Encyclopedia of marine mammals. Academic Press, San Diego, CA.

NITTA, E. 1987. The marine mammal stranding network for Hawai'i, an overview. NOAA Technical Report NMFS 98:55-62.

Ohizumi, H., H. Watanabe, M. Moku and S. Kawahara. 2001. Species identification for otoliths of myctophid fishes in the western North Pacific. Aquabiology 137:626637.

PLÖN, S. 2004. The status and natural history of pygmy (Kogia breviceps) and dwarf (K. sima) sperm whales off southern Africa. Ph.D. dissertation, Rhodes University, Grahamstown, South Africa. xvii + 533 pp.

Reid, S. B., J. Hirota, R. E. Young and L. E. Hallacher. 1991. Mesopelagic-boundary community in Hawai i: Micronekton at the interface between neritic and oceanic ecosystems. Marine Biology 109:427-440.

Roper, C. F. E., AND R. E. Young. 1975. Vertical distribution of pelagic cephalopods. Smithsonian Contributions to Zoology 209:1-51.

Ross, G. 1979. Records of pygmy and dwarf sperm whales, genus Kogia, from southern Africa, with biological notes and some comparisons. Annals of the Cape Provincial Museums (Natural History) 11:259-327.

SANDERS, N. K., AND J. J. Childress. 1990. Adaptations to the deep-sea oxygen minimum layer: Oxygen binding by the hemocyanin of the bathypelagic mysid, Gnathophausia ingens Dohrn. Biological Bulletin 178:286-294.

Santos, M., G. Pierce, A. Lopez, R. Reid, V. Ridoux and E. Mente. 2006. Pygmy sperm whales Kogia breviceps in the northeast Atlantic: New information on stomach contents and strandings. Marine Mammal Science 22:600-616.

SeKiguchi, K., N. Klages And P. Best. 1992. Comparative analysis of the diets of smaller odontocete cetaceans along the coast of Southern Africa. South African Journal of Marine Science 12:843-861.

Shallenberger, E. W. 1981. The status of Hawaiian cetaceans. Final report to the U.S. Marine Mammal Commission MMC-77/23. 70 pp.

Smale, M. J., G. Watson AND T. Hecht. 1995. Otolith atlas of southern African marine fishes. Icthyological Monographs of the J. L. B. Smith Institute of Ichthyology 1, Grahamstown, South Africa.

Spear, L. B., D. G. Ainley and W. A. Walker. 2007. Foraging dynamics of seabirds in the eastern tropical Pacific ocean. Studies in Avian Biology No. 35:1-99.

Struhsaker, P. 1973. A contribution to the systematics and ecology of Hawaiian bathyal fishes. Ph.D. dissertation, University of Hawai 'i, Honolulu, HI. xv +482 pp.

WANG, M., W. Walker, K. ShaO AND L. ChOU. 2002. Comparative analysis of the diets of pygmy sperm whales and dwarf sperm whales in Taiwanese waters. Acta Zoologica Taiwanica 13:53-62. 
Young, R. E. 1975. Transitory eye shapes and the vertical distribution of two midwater squids. Pacific Science 29:243-255.

YounG, R. E. 1978. Vertical distribution and photosensitive vesicles of pelagic cephalopods from Hawaiian waters. Fishery Bulletin 76:583-615.

Received: 23 May 2008

Accepted: 1 January 2009 